\title{
スポーツイベントにおけるスポンサーフィット： 先行研究の検討
}

\author{
Sponsor Fit at Sporting Events: A Literature Review
}

\section{山口志郎 ${ }^{1)}$}

1 ) 流通科学大学

\begin{abstract}
Although the fit between a sponsor and an object (e.g., event, sponsored organization, and endorser) in sport has been shown to be an important construct in predicting sponsorship effects, little attention has been given to understand the concept of sponsor fit. The purpose of this study was to review the literature on sponsor fit at sporting events. This paper was consisted of four categories: 1) construct of sponsor fit, 2) theoretical development of sponsor fit, 3) measurement and methodology of sponsor fit, and 4) the antecedents and consequences of sponsor fit on consumer behavior. This paper also provides directions for future research that focuses on the development of new concept based on traditional marketing concepts such as personality fit and portfolio fit, as well as the development of integrated model for sponsor fit including moderator variables.
\end{abstract}

Key words: sport marketing, sponsor fit, sporting events, literature review キーワード : スポーツマーケティング、スポンサーフィット、スポーツイベント、文献研究

\section{連絡先 :}

山口志郎

流通科学大学

干 651-2188 神戸市西区学園西町 3 丁目 1 番
Address Correspondence to:

Shiro Yamaguchi, University of Marketing and Distribution Sciences

3-1 Gakuen-Nishimachi, Nishi-Ku, Kobe, Hyogo, 651-2188, Japan E-mail: Shiro_Yamaguchi@red.umds.ac.jp 


\section{はじめに}

今日、スポーツを取り巻く社会情勢は、かつて われわれが経験したことのない速さと多様性を持 ちながら、変化と発展を遂げている。これは、イ ンターネットや携帯電話の普及、さらにはブログ やSNS（e.g., Facebook, LINE, Twitter) などの情報 化社会の進展に伴い、その中で生活する人々の「個 性化」と「自由化」が進行し、スポーツへの関わ り方も、「する」「みる」、「ささえる」などマクロ な広がりをみせているためである。

こうした中、スポーツマネジメント領域におけ るスポンサーシップ産業は目覚ましい発展を遂げ ており、スポンサーシップという言葉も市民権を 得つつある。McCarville and Copeland (1994, p.103) は、スポンサーシップを「スポーツ組織とスポン サー企業が同等の価值を交換し、お互いにメリッ 卜を共有する相互交換関係」と定義している。ス ポーツ組織は、スポンサーシップ契約を通して、 企業から金銭・製品・サービスを享受し、企業は スポーツ組織から同価格と評価されるブランドの 露出、ブランドイメージ向上、及びホスピタリ ティの寄与などの便益を受ける。こうした交換関 係、すなわち win-win の関係が構築されることに より、スポンサーシップ契約は成立する。現在、 世界各地で開催されるスポーツイベントは、オリ ンピック・パラリンピック競技大会や FIFA ワー ルドカップ、ラグビーワールドカップに代表され るメガ・スポーツイベントから、東京マラソンや 日本スリーデーマーチ、マスターズ甲子園などに 代表される生涯スポーツイベントまで多種多様で あり、それらのイベントを成功させるためには、 スポンサーシップ収入は必要不可欠な財源と言え る。

一方、学問領域では、欧米においてスポンサー シップ研究が独自の領域として生まれ、確立する 基盤ができたのは 1980 年代半ばである。Cornwell and Maignan（1998）によると、1980 年代半 ばから 1990 年代半ばにかけては、主にスポン サーシップの発展を国別ごとに記述する研究やス
ポンサーシップの定義に関する研究が多く行われ たことを報告している。これらの現象は、1984 年のロサンゼルスオリンピックにおける商業化、 オフィシャルスポンサー制度の導入が大きく起 因したことが考えられる。また、Cornwell and Maignan（1998）は、スポンサーシップに関する 代表的な文献を 80 件レビューした結果、スポン サーシップの研究動向として以下の 5 つに分類 を行っている。すなわち、（1）スポンサーシッ プの特性、（2）スポンサーシップの経営的側面、 (3) スポンサーシップの効果測定、(4) スポンサー シップの戦略的活用、（5）スポンサーシップに おける法的、または倫理的な問題の 5つである。

Walliser (2003) は Cornwell and Maignan (1998) によって確認された 80 件の研究に加え、2003 年までに発表された 153 件の研究資料を吟味し た上で、スポンサーシップの定義は成熟期に達し たものの、スポンサーシップを適切に評価する 指標は不十分であることを指摘している。これ は、McDaniel（1999）や Ruth and Simonin (2003) も同様の見解を示している。その後 Cornwell and Kwon (2010) は、Cornwell and Maignan (1998) に よって確認された $5 つ の$ 分類の内、スポンサー シップの特性に関する研究は一般的に受け入れら れてきたため減少傾向にあり、一方でスポンサー シップの効果測定に関する研究は、大幅に増加し たことが報告されている。また、ブランド・エク イティやアンブッシュ・マーケティングの効果に 関する研究が新しい研究テーマとして発展したこ とも合わせて報告している。そうした流れを受け、 Cornwell（2012）は、1996 年から 2011 年の主 要ジャーナル (e.g., Journal of Advertising) に掲載 されているスポンサー研究を概観した上で、今後 のスポンサーシップ研究は、(1) スポンサーシッ プのクラッター（混雑度）とフィット、(2) ス ポンサーシップの交換、(3) スポンサーシップ の統合、（4）スポンサーシップのポリシーとプ ログラムに注目する必要があると述べている。本 研究では、これらの研究領域の中から、スポンサー シップのフィット（以下スポンサーフィットとす る)の研究に焦点を当てることとした。なぜなら、 
スポンサーフィットは、スポンサーシップの刺激 の処理に関連する最も広く使用されている理論的 な概念の一つであり、これまで広告・消費者研究 において、頻繁に研究されてきたトピックだから である (Cornwell et al., 2005; Olson and Thjomoe, 2011)。

山口ほか (2010, p.152) は、スポンサーフィッ トを「イベントとスポンサーの適合度」と定義し ており、イベントが持つイメージとターゲット企 業の製品やブランドのイメージに適合性がある かを示す指標である（藤本, 2008)。これまでの スポンサーフィット研究は、イベントとスポン サーが消費者の記憶中で知覚的に一致すること で、イベントのイメージがスポンサーのイメージ に転移し (e.g., Gwinner and Eaton, 1999; Herrmann et al., 2011; Zdravkovic and Till, 2012)、消費者はス ポンサーに対し、好意的な態度や行動を示すこと が報告されている (e.g., Simons and Becker-Olsen, 2006; Gwinner and Bennett, 2008)。したがって、 スポンサーフィットの有効性は確認されている。 しかしながら、スポンサーフィットの研究のほと んどが欧米で行われたものであり、それらの研究 が日本のコンテクストに当てはまるかは疑問が残 る。また、欧米を中心にスポンサーフィットの定 義や測定尺度の議論が活発になされてきたが、日 本においてはほとんど行われていないのが現状で ある。わが国に抽は、辻（2011）がスポン サーシップの研究動向をレビューした中で、スポ ンサーフィット研究について取り上げているもの の、当該概念を用いた基礎研究や応用研究につい てはほとんど言及されていない。そこで本稿では、 我が国のスポーツマーケティング及びスポンサー シップに関する研究の発展に寄与するため、これ まで欧米で行われたスポーツイベントにおけるス ポンサーフィットに関する研究動向を整理し、大 局的かつ客観的に総括することを目的とする。

\section{レビューの手続き}

本研究では、Hsieh and Shannon（2005）の質的 内容分析 (qualitative content analysis) における 3
ステップアプローチを参考に、記述的レビュー を実施した。1つ目のステップとして、スポン サーフィットに関する国内外の先行研究の収集を 行った。具体的には、EBSCO Information Services が製作するデータベース「EBSCOhost」、ルゼ ビア社が製作するデータベース「Science Direct」 を中心に、国外のスポンサーフィットに関する 研究論文を収集した。また補足として、CiNii と Google scholarを活用し、国内外の関連論文を収 集した。その際、タイトルと掲載雑誌名からスク リーニングを行い、研究目的に適合するスポン サーフィットの文献とその他関連となる文献を収 集した。2つ目のステップとして、Cornwell and Maignan（1998）と Walliser（2003）のレビュー 研究を基に、本研究の分類を行った。そして 3 つ目のステップとして、分類を行った先行研究を 基に、総括的なレビューを試みた。なお本研究に おけるスポンサーフィットは、スポンサーシップ のフィットを含めた用語と操作定義する。

\section{スポンサーフィット研究の動向}

吉田（2011）によると、新たな研究課題とし て普及・拡大し、学問的知識体系の中で十分な理 論的説明を加えるまでには、三つの研究ステー ジを踏む必要があると述べている。3つの研究ス テージとは、（1）構成概念の検討（e.g., 概念の 定義、多次元の検討)、(2) 説明変数と目的変数 を含めた要因間の関係性の検討、（3）要因間の 関係性の強弱を決定づける環境や対象を絞り込む ための調整変数の検討である。そこで本研究で は、国内外のデータベースを基に抽出された論文 から、吉田（2011）の見解並びに Cornwell and Maignan（1998）と Walliser（2003）の分類を基に、 スポンサーフィット研究のレビューを行った。そ の結果、（1）スポンサーフィットの構成概念に 関する研究、(2) スポンサーフィットの理論的 アプローチに関する研究、(3) スポンサーフィッ トの測定尺度と方法論に関する研究、(4) スポ ンサーフィットの先行要因と結果要因に関する研 究の 4 つに分類することができた。 


\section{1. スポンサーフィットの構成概念に関する研究}

\section{1. スポンサーフィットの定義}

スポンサーフィットの概念を検討する上で、ま ずはスポンサーとフィットの 2 つ語で構成さ れる概念であることを確認する必要がある。一般 的にスポンサーとは、電波媒体の広告主あるいは スポンサーシップを行う団体、個人を指しており （池上，2006）、様々な媒体を利用して広告する 企業と言われている（原田・小笠原，2008）。企 業がスポンサーとしてスポーツにかかわる場合、 企業はスポーツが所有するブランド資産を独占す る権利を買い取り、スポーツ側は、その金額に見 合った価值を提供する。スポーツのブランド資産 の中には、スポーツイベント、チーム・クラブ、 リーグ、競技団体、スポーツ施設、アスリート、 関連インフラなど、これらすべてがスポンサー投 資の対象となる（原田，2007）。スポーツイベン トを例に挙げると、数多くの企業名や商品・サー ビス名の看板がイベント会場に並び、選手のユニ フォームや関連グッズにもそれらを概観すること ができる。またマスメディアを通して、スポーツ イベントのスポンサーは多くの視聴者の目にも留 まる。したがって、スポンサーとは単に資金面で の後援者や商業放送の広告主ではなく、スポン サー企業の目的に応じて、様々なべネフィットを スポンサー対象から得ることが可能となる。そこ でこれまでの先行研究の整理から、スポーツに対 するスポンサーを「スポーツイベント、チーム・ クラブ、リーグ、競技団体、スポーツ施設、アス リート、関連インフラなどに対し、企業目的及び マーケティング目的を達成するために金銭を支払 う企業あるいは個人」と定義する。

一方フィットとは、（1）関連、（2）適合、（3） 調和、（4）一致などと日本語に訳され、コンテ クストに基づいてそれらの用語は使用される。 Fleck and Quester（2007）によると、マーケティ ング研究におけるフィットは、ブランド戦略から マーケティング・コミュニケーションに至る様々 な領域に関連した研究が行われてきたことを報告 している。また Tauber（1988）によると、ブラン
ド拡張研究におけるフィットは、一致として概念 化されており、新製品が消費者によってブランド から論理的に判断された際、フィットは生じるこ とを報告している。Aaker（1991）は、ブランド 拡張の成功条件として、当該ブランドのイメージ と拡張先商品カテゴリーの持つイメージが一致す ることが重要だと指摘している。Kamins（1990） によると、広告研究では、製品とエンドーサーと のフィットが広告効果を改善できると報告してい る。しかしながら、Zdravkovic et al. (2010) によ ると、これまでマーケティングや広告研究におい て盛んにフィットの重要性が叫ばれてきたにもか かわらず、フィットという言葉自体は漠然に使用 されており、フィットの性質が何であるかにつ いてはあまりコンセンサスが得られていないの が現状である（Nan and Heo, 2007）。これまでの マーケティング研究から得られたコンセンサスで は、一般的にフィットは類似性の消費者知覚とし て認識されており（Rifon et al., 2004）、消費者に とってポジティブな要因として捉えられる傾向に あることから、新製品の紹介や消費者のメッセー ジ処理を手助けするのに役立っている（Fleck and Quester, 2007)。

スポンサーシップ研究においてフィットの概念 化が議論され始めたのは 1990 年代半ばからであ る。 Jagre et al.（2001）によると、フィットの構 造を概念化する際、研究者は多数の専門用語を使 用しながら異なったアプローチで研究が行われて きたことを報告している。例えば、フィットを類 似性(Gwinner,1997; Gwinner and Eaton, 1999)、マッ チアップ (McDaniel, 1999)、関連性（McDonald, 1991; Johar and Phan, 1999)、一貫性（Jagre et al., 2001)、相互作用（Ruth and Simon, 2003）、及び一 致 (Speed and Thompson, 2000）の視点から概念 化する研究がある。これまでのスポンサーフィッ トの代表的な定義を系統的に紹介すると、McDonald（1991, p.34）は関連性の視点から、スポ ンサーフィットを「イベントとスポンサー間の直 接的、または間接的な関連性の程度」と定義して いる。McDaniel (1999, p.167) は、マッチアップ の視点から、スポンサーフィットを「製品の機能 
性、ブランドイメージの属性、及びイベントイメー ジの属性との間の知覚された類似性」と定義して いる。Johar and Pham（1999, p.300）は、関係性 の視点から、消費者の類似性を「イベントの特徴 とそれらの潜在的なスポンサーとの間の意味論 的な重複」と定義している。 Speed and Thompson (2000, p.230) は適合性の視点から、スポンサー フィットを「イベントとスポンサーの組み合わせ に対する受け手の態度、またはその組み合わせが どれ程適合、調和しているか」と定義している。 Jagre et al.（2001, p.441）は、一貫性の視点から、 スポンサーフィットを「消費者の知覚や予測に基 づき、イベントにスポンサードしている企業のブ ランド、製品、及びサービスとの知覚された親密 さ」と定義している。Simmons and Becker-Olsen （2006, p.155）は、類似性の視点から、スポンサー フィットを「イベントとそのスポンサードしてい るブランドが類似したイメージ、価值、及び論理 的な結びつきを知覚する程度」と定義している。

スポンサーフィットの概念化及び操作化は、理 論的、方法論的アプローチから十分な流動性を 持って研究が行われてきたにもかかわらず（McDaniel, 1999; Rifon et al., 2004)、いまだ研究者間 で統一した定義がなされていないのが現状であ る。なぜなら、フィットには、類似性の多次元的 な性質が含まれているためである。例えば、心理 学において、類似性には無数の潜在的な側面が含 まれていることが報告されている (Simon et al., 1970)。また、マーケティング研究においても、 フィットには多数の側面があることが言及され ている（Keller, 2003)。そして、スポンサーシッ プ研究においても、フィットには機能的な特徴や 象徴的な特徴に基づいて確立された多数の側面が あることが指摘されている (Speed and Thompson, 2000)。しかしながら、多くのスポンサーフィッ 卜研究において、フィットは類似性の視点から概 念化されることが多く、またマーケティング研 究においても同様の系統を辿っていることから、 著者もこの見解を支持する。なぜなら、Simmons and Becker-Olsen（2006）によると、企業とスポ ンサー対象が類似性として知覚された場合、それ
らの関係は高まることを指摘し、類似性はブラン ドコンセプトや属性、テクノロジー、マーケッ ト、製品、ミッションから由来しているためであ る。そこで、これまでの概念整理を基に、スポン サーフィットを類似性（similarity）の視点から、 「記憶内の知識と予測に基づく、イベントとスポ ンサーとの間の知覚された類似性」と定義する。

\section{2. スポンサーフィットの構造}

スポンサーフィットの構造に関する研究とは、 複数項目からなるスポンサーフィットの項目を要 因（次元）に分類した研究のことである。これ までイメージに基づく類似性の研究 (Speed and Tompson, 2000; Simmon and Becker-Olsen, 2006)、 またはイメージに基づく類似性と機能に基づく 類似性の 2 つに分類する研究 (Gwinner, 1997; Gwinner and Eaton, 1999; Rifon et al., 2004) が多く 行われてきた。

1 次元性のフィットについて、Speed and Tompson（2000）は、1つの構成概念に着目し、スポ ンサーフィットをモデル化することで、消費者 の一般的なスポンサーフィットを概念化できる と報告している。Gwinner and Bennett (2008) や 山口ほか（2010）は、この見解を支持し、スポ ンサーフィットに影響を及ぼす要因を含むモデ ルの検討を行っている。他にも多くの研究者に よって、1 次元性の観点から、他の変数 (e.g., ス ポンサーへの態度、反応、購入意図) を含めた包 括的なモデルの検証が行われている（e.g., Speed and Tompson, 2000; Martensen et al., 2007; Close and Lacey, 2013; Han et al., 2013)。

一方、Gwinner（1997）は、スポンサーフィッ トにはイメージに基づく類似性と機能に基づく類 似性の 2 つの要因があることを明らかにしてい る。イメージに基づく類似性とは、スポンサード しているブランドのイメージとイベントのイメー ジに関連性がある時に生じる。機能に基づく類似 性とは、スポンサードしている製品がイベントの 間に参加者によって使用された時生じる。Gwinner and Eaton（1999）は、イメージに基づく類似 性と機能に基づく類似性のどちらの組み合わせで も、スポンサーを認知することでイベントからブ 
ランドへのイメージの転移が発生することを明ら かにしている。

しかしながら、Pentecost and Spence（2009）に よると、機能に基づく類似性は、使用に基づく類 似性と性質に基づく類似性に分類できると主張し ており、スポンサーフィットにはイメージの類似 性を含んだ 3 次元で測定することが適切だと指 摘している。言い換えれば、スポンサー製品の使 用に基づく類似性とイベント性質に基づく類似性 と解採することができる。この主張に至った理由 として、スポンサードしているブランドの特性は、 参加者のイベント経験に基づき、連想は供給され るためである。

Smith（2004）は、Keller（1993）のブランド知 識構造を基に、1）製品特質、2) ユーザーイメージ、 3）ブランド・パーソナリティ、4）機能的ベネ フィット、5）経験的ベネフィット、6）象徵的 ベネフィットの 6 次元からスポンサーフィット を概念化できることを明らかにしている。 Smith の研究は、Pentecost and Spence（2009）の主張で 明らかになった、イメージ、使用、及び性質に基 づく類似性の問題点を解決することができ、スポ ンサーフィットの大部分の概念化を説明するこ とが可能となる。しかしながら、Smith の研究は 理論的枠組みの提案に留まっているため、今後 Keller（1993）のブランド知識構造を基にしたス ポンサーフィットの実証的研究を行う必要がある だろう。

こうして先行研究の蓄積によって、スポンサー フィットには多次元性の性質があることが立証さ れている。その一方で、近年の研究では、スポン サーフィットには下位次元があるという仮説の 基、それらの下位次元が全体のスポンサーフィッ ト（もしくはグローバルフィット）に影響を及 ぼすか検証が行われている。例えば、Fleck and Quester（2007）は、スポンサーフィットの下位 次元を関連性と予測性に設定し、それらの変数が 全体のスポンサーフィットに影響を及ぼすことを 確認している。Zdravkovic et al. (2010) は、確認 的因子分析の結果に基づき、10 の下位次元（可 視性、明白さ、スローガン、ミッション、カラー、
ターゲット、プロモーション、地理的適合性、 ローカル特性、関与）を提案している。 Drenger et al.（2011）は、イメージに基づく一致、機能に 基づく一致、そしてユーザーに基づく一致がグ ローバルフィットに影響を及ぼすことを明らかに している。ユーザーに基づく類似性は、イベント ユーザー（e.g., 観戦者、訪問者）とブランドユー ザー（e.g., 消費者）を指し、彼らは互いに類似し た見解を持っているため、スポンサーとイベント との間のより強いフィットを知覚する可能性を秘 めている。Olson and Thjømøe（2011）は、インタ ビュー調査と先行研究の概念整理を基に、使用、 卓越、観衆の類似性、地理的な類似性、態度の類 似性、及びイメージの類似性の 6 つの下位次元 があることを明らかにし、それらの変数はブラン ドやイベントのコンテクストによって、全体のス ポンサーフィットに影響を及ぼす要因は異なるこ とを確証している。

以上のことから、スポンサーフィットには、多 次元性、下位次元があることが明らかとなった。 また、研究者のアプローチの仕方やイベントのコ ンテクストの違いに基づき、スポンサーフィット の構成要素や影響要因は異なることが示された。 今後わが国において、スポンサーフィットの構造 を検討する際は、これらの先行研究を参考にする と共に、イベント開催国の社会文化的な背景を考 慮した尺度開発が望まれる。表 1 には、スポンサー フィットの構造を比較した研究を示している。

\section{2. スポンサーフィットの理論的アプローチに関 する研究}

これまでのスポンサーフィット研究は、社会心 理学や認知心理学の理論を用いながら様々な実証 的研究が行われてきたが、一般的にスポンサー フィットは、一致理論やスキーマ理論を用いて 説明されることが多い (Cornwell et al., 2005; 辻, 2011)。一致理論とは、消費者が彼らの事前予測 と関係した一致情報を記憶から思い起こす。その 際、記憶された情報とその検索は、スポンサード しているブランドとスポンサードされたイベン トとの類似性もしくは関連性によって影響され 


\begin{tabular}{|c|c|c|c|c|}
\hline 著者（発行年数） & 対象者 & デザイン & $\begin{array}{l}\text { 要因数 } \\
\text { (項目数) }\end{array}$ & 多次元（副次元） \\
\hline Gwinner and Eaton (1999) & 米国の大学生 360 名 & 横断研究 & 2(6) & 1）イメージ、2）機能 \\
\hline Speed and Tompson (2000) & オーストラリアの大学生 237 名 & 横断研究 & $1(5)$ & イメージ \\
\hline Smith (2004) & - & 概念枠組み & - & $\begin{array}{l}\text { 1）製品特質、2）ユーザーイメージ、3) } \\
\text { ブランド・パーソナリティ、4）機能 } \\
\text { 的ベネフィット、5）経験的ベネフィッ } \\
\text { ト、6）象徴的ベネフィット }\end{array}$ \\
\hline Pentecost and Spence (2009) & オーストラリアの大学生 171 名 & 横断研究 & $3(9)$ & 1）イメージ、2）使用、3）性質 \\
\hline Fleck and Quester（2007） & 18 歳から 70 歳の一般消費者 780 名 & 横断研究 & $2(5)$ & 1）関連性、2）予測性 \\
\hline Zdravkovic et al. (2010) & 米国の大学生 862 名 & 横断研究 & $10(31)$ & $\begin{array}{l}\text { 1) 可視性、2）明白さ、3）スローガン、4） } \\
\text { ミッション、5）カラー、6）ターゲット、 } \\
\text { 7）プロモーション、8）地理的適合性、 } \\
\text { 9）ローカル特性、10）関与 }\end{array}$ \\
\hline Drenger et al. (2011) & ドイツのイベント参加者 108 名 & 横断研究 & $3(6)$ & 1）イメージ、2）機能、3）ユーザー \\
\hline Olson and Thjømøe (2011) & ノルウェーの一般市民 285 名 & 横断研究 & $6(17)$ & $\begin{array}{l}\text { 1）使用、2）卓越、3）観衆、4）地理、 } \\
\text { 5）態度、6）イメージ }\end{array}$ \\
\hline
\end{tabular}

る (Cornwell et al., 2005)。言い換えれば、関係性 や類似性のある企業、ブランドの方がよりスポン サーとして認識されやすくなる（辻，2011）。例 えば、プロテニストーナメントにおいて、他業種 の企業・ブランドがそのイベントのスポンサーに なるより、スポーツ用品メーカーがスポンサーに なった方が、消費者はその企業をスポンサーとし て認識されやすくなる。

また一致理論と類似した理論として、Sirgy et al. (2008) と Quester et al.（2014）は、自己一致 理論をスポンサー研究に適用し、実証的研究を 行っている。自己一致理論とは、自らの自己イ メージに一致するようなユーザーイメージを持っ たグッズやサービスを使用、もしくは購入するこ とを選択する (Sirgy et al., 2008)。そうすることで、 消費者は彼ら自身の見解や個人のアイデンティ ティを強化する。また好意的な態度や購入意図を 持つブランドを所持することによって、消費者は 自己一致を達成した商品やコンセプトに対して類 似性を知覚する。

一方で、スキーマ理論におけるスキーマとは、 「刺激の概念や類型について知ることを表す認識
構造であり、その属性と属性間の関係性を含む」 と定義されており（Fiske and Taylor, 1991, p.98）、 過去の経験や外部環境を通じて発達する構造化さ れた知識とも言われている（Bartlett, 1932）。この スキーマ理論をスポンサーフィット研究に適応す ると、イベントとスポンサーの連想が顕著になる と、消費者が二者間のスキーマのフィットを評価 したと考えることができる（山口ほか，2010）。 そうすることで、スキーマ間で一致したスポン サーフィットは、他のブランドよりスポンサード しているブランドを好意的に評価する。 Musante et al. (1999) によると、スキーマ理論は、スポン サー研究において、人々の評価を測る上で、有効 な視点になることを報告している。

しかしながら、一致理論やスキーマ理論以外に も様々な研究者によって、いくつかの理論的アプ ローチの検証が行われている。以下にいくつかの 理論を紹介したい。Cornwell et al.（2006）は、連 想ネットワーク理論を用いて、スポンサーフィッ トの実験的研究を行っている。連想ネットワーク 理論とは、無数のノードとそれらを互いに結びつ けるリンクをネットワークとして記憶を捉える理 
論である（Collins and Loftus, 1975)。ノードは頭 の中に蓄えられた情報や概念のことであり、リ ンクは情報や概念にまつわる連想のことを指す。 Drenger et al. (2011) によると、共有されたリン クは、ブランドとイベントとの間に存在し、それ らの連想の強さは、対象との知覚された一致に影 響されると述べている。Cornwell et al. (2006) は、 実験的研究を通して、スポンサーとイベントとの フィットが低い場合、そのフィットをプレスリ リース ${ }^{1)}$ を用い説明することで、スポンサー想 起が向上することを明らかにしている。

次に帰属理論とは、低い事前確率を伴う事象に 向き合った人々は、確率を高められるだけの原因 を探るよう動機づけられる（Kelley, 1973）。言い 換えれば、通常は結び付きづらい企業やブランド がイベントのスポンサーとなった場合、消費者は イベントとスポンサーを結び付けられるよう動機 づけられる。Rifon et al. (2004) は、帰属理論を 用い、スポンサーフィットの一致効果が利他的な 動機、スポンサーへの信頼性、及びスポンサーへ の態度に影響を及ぼすことを明らかにしている。 また Deitz et al. (2012) は、帰属理論、社会的ア イデンティティ理論、及びスキーマ理論を用いな がら、スポンサーフィットの実証的研究を行って いる。

最後に、マッチアップ仮説とは、有名人が持つ ているイメージ及び製品並びにブランドの特性が 一致する際に、有名人は製品及びブランドに対 する評価を強化することができるとされている (McDaniel, 1999)。Roy and Cornwell (2003) は、 マッチアップ仮説を使い消費者がスポンサーシッ プをどのように評価するか説明しており、論理的 なリンクまたは戦略的なリンクのどちらかをスポ
ンサーシップにおいて説明することにより、消費 者の好意的な反応を発展させることができると報 告している。

スポンサーフィットの理論は、これまで様々な 研究者によって社会心理学や認知心理学の観点か ら理論的構築が行われてきた。それぞれの理論ご とに説明可能な範囲があり、どの理論を用いてス ポンサーフィットの現象を説明するかは研究者の 立ち位置に委ねられる。今後はそれぞれの理論を 補完しながら、スポンサーフィットの現象を理論 的アプローチに基づいた科学的な研究結果を示す 必要があるだろう。表 2 には、スポンサーフィッ トの理論的枠組みを示している。

\section{3. スポンサーフィットの測定尺度と方法論に関 する研究}

\section{1. データ収集の方法}

過去のマーケティング研究では、一般的にス ポンサーシップ効果の測定が不十分な点が懸念 されており (Cornwell and Maignan, 1998; Walliser, 2003)、スポンサーシップから派生した概念であ るスポンサーフィット研究も同様の変遷を辿って いる。Cornwell et al. (2005) は、スポンサーシッ プ効果の測定方法を、(1) フィールドワーク研究、

（2）実験的研究の 2 つに分類を行っている。

フィールドワーク研究においては、1990 年代 から 2000 年代にかけて主にスポンサーシップ想 起やブランド効果の測定をワンショットサーベ イで行う研究が多くを占めた (e.g., Javalgi et al., 1994; Pham and Johar, 2001; Speed and Thompson, 2000; Ruth and Simonin, 2003)。近年は、縦断的調 査を行う研究が増加しており、時間軸によって スポンサーシップ効果が変化するのか検証が行

表 2 スポンサーフィットの理論的枠組み

\begin{tabular}{lll}
\hline & 理論 & \multicolumn{1}{c}{ 代表的な先行研究 } \\
\hline Congruity theory & 一致理論 & Roy and Cornwell, 2004; Gwinner and Bennett, 2008 \\
\hline Schema theory & スキーマ理論 & Musante et al., 1999; Roy and Cornwell, 2003 \\
\hline Self-congruity theory & 自己一致理論 & Sirgy et al., 2008; Quester et al., 2014 \\
\hline Associative networks & 連想ネットワーク理論 & Cornwell et al., 2006; Drenger et al., 2011 \\
\hline Attribution theory & 帰属理論 & Rifon et al., 2004; Deitz et al., 2012 \\
\hline Match up hypothesis & マッチアップ仮説 & McDaniel, 1999; Roy and Cornwell, 2003 \\
\hline
\end{tabular}


われている (e.g., Stipp, 1998; Woisetschlager and Michaelis, 2012)。しかしながら、同一サンプルで 縦断的調査を行うことは困難なことから、結果と して、個人レベルでの消費者のスポンサーシップ 効果が変化したかは不明瞭なままである。

一方で、実験的研究に関しては、2000年代 からイメージの転移やメモリー効果において、 スポンサーフィットは重要だと指摘されている (Becker-Olsen and Hill, 2006; Rifon et al., 2004; Simons and Becker-Olsen, 2006; Cornwell et al., 2006)。 Woisetschlager and Michaelis（2012）によると、実 験的研究はフィールドワーク研究より高いレベル で内的妥当性が提供できることを報告している。 一方で外的妥当性においては、スポンサーフィッ トは本質的に静的なものと見なされているが、時 間の経過とともにスポンサーフィットの結果は変 化する可能性が考えられる。したがって、実験的 研究による外的妥当性は不明暸なままである。

そうした中、Cornwell et al. (2005) は、スポンサー シップ効果の研究方法について、一般的なマーケ ティング戦略では、スポンサーシップという媒体 のみで消費者に情報伝達するわけではなく、多種 多様な媒体、方法を用いてプロモーションを行 うことを報告している。したがって、他のプロ モーション効果がブランド効果やブランドイメー ジ向上に影響をしていることが考えられる（辻, 2011)。よって、純粋にバイアスのない状態でス ポンサーフィットが測れているかは定かではな い。これらの理由により、Cornwell et al. (2005) は真のスポンサーシップ効果をフィールドワーク 研究で測定するのは難しいと指摘しており、真の スポンサーシップ効果及びスポンサーフィットを 測定するためには実験的研究を行い、他の効果を 無効化する必要があると述べている。これは、辻 （2011）も同様の見解を示しており、先行研究の 整理を基に、今後は実験的研究に基づき、フィー ルドワーク研究を行う必要があると報告してい る。一般的なフィールドワーク研究では、母集団 を特定しながら、無作為抽出法（ランダムサンプ リング）を行い、外的妥当性を担保することが求 められるが、スポンサーシップ研究では、ある特
定のスポンサーやカテゴリーの異なるスポンサー (e.g., 冠協賛スポンサーvs. 協賛スポンサー) を 対象に調查を行うことから、母集団の特定が困難 であり、厳密な意味での悉皆調査や無作為抽出法 (ランダムサンプリング）による標本調査を行う ことが困難である。したがって、スポンサーシッ プ及びスポンサーフィット研究では、1つ1つの 現象を丁寧にケーススタディとしてまとめること が重要であり、その際辻（2011）が提案するよ うに、実験的研究を基にしたフィールドワーク研 究を行うことで、より対象を深く掘り下げた研究 結果を世に送り出すことができるだろう。

\section{2. スポンサーフィットの測定指標}

スポンサーフィットの測定は、様々な研究者に よって分析が行われてきた。例えば、単一の項 目でフィットを測定する研究 (D’ Astous and Bitz, 1995; Johar and Pham, 1999)、複数の項目でフィッ トを 1 次元の視点から測定する研究 (Speed and Tompson, 2000; Roy and Cornwell, 2003; Week et al., 2008）、イメージに基づく類似性から測定する研 究 (Gwinner and Eaton, 1999; Musante et al., 1999; Koo et al., 2006; Pentecost and Spence, 2009; Drenger et al., 2011)、機能に基づく類似性から測定する研 究 (Gwinner and Eaton, 1999; Drenger et al., 2011)、 機能に基づく類似性を使用に基づく類似性と性質 に基づく類似性に分類し測定する研究（Pentecost and Spence, 2009)、そしてユーザーに基づく類似 性から測定する研究 (Drenger et al., 2011) などが 行われている。

これまでスポンサーフィットの有効性に関して は、様々な研究者や実務家の努力によって立証さ れてきたが、理論に基づく実証的な尺度開発はあ まり行われておらず、いくつかの測定尺度は単一 の項目で測定されるなど広範囲なものが多いこと が懸念されている (Fleck and Quester, 2007)。そ のため、スポンサーフィットを経営的な意思決定 プロセスに適用する際には検討の余地が残されて いる。なぜなら、現在までにスポンサーフィット の多次元性（下位次元を含む）を測定・発展させ た研究は、わずか 6 件に留まっているためである (Gwinner and Eaton, 1999; Fleck and Quester, 2007; 
Pentecost and Spence, 2009; Zdravkovic et al., 2010; Drenger et al., 2011; Olson and Thjømøe, 2011)。 またこれまでの先行研究では、異なったアプ ローチによる尺度が適用されている。例えば、 シングルアイテム尺度（e.g., D’ Astous and Bitz, 1995; Johar and Pham, 1999)、リッカートタイプ 尺 度 (e.g., McDaniel, 1999; Speed and Thompson, 2000)、セマンティック・ディファレンシャル 尺度 (以下 SD 法とする ; e.g., Roy and Cornwell, 2003; Rifon et al., 2004）などである。 Drenger et al.（2011）によると、SD 法は歪められたリスク を招く可能性があり、リッカートタイプ尺度の方 がスポンサーフィットを測定するには好ましいと 指摘している。一方で、実用的な視点から考えれ ば、シングルアイテム尺度の方が使用しやすいと している。

以上のことから、スポンサーフィットの測定に は、様々な尺度が適用され、研究者のリサーチデ ザインやアプローチ方法の違いに基づき、異なっ た尺度が選択されてきたことが推察される。今後 これらの尺度を使用する際は、研究者が描くリ サーチデザインに基づき、適切な尺度を選択する ことが必要であろう。例えば、スポンサーフィッ トを変数の 1 つとして含めた包括的なモデルの 検証を行う場合は、これまで多くのスポンサー フィット研究で引用されてきた Speed and Thompson（2000）の 1 次元 5 項目尺度を使用すること が望まれる。これは、Cornwell (2014) も同様の 見解を示しており、個人はイベントのための個人 的な連携を持っており、イベントによりフィッ トするスポンサーを好意的に評価する傾向にあ る。したがって、Speed and Thompson（2000）の 尺度はこうした点が考慮されているため高いレべ ルで信頼性と内容的妥当性を確保することができ るであろう。また、スポンサーフィットの多次元 性を厳密に測定したい場合は、Olson and Thjømøe (2011) が行ったスポンサーフィット研究の枠組 みと尺度（6 次元 17 項目）を参考にリサーチデ ザインを作成することが望まれる。最後に、実務 的な視点から、A4一枚程度の質問紙調査をフィー ルドワークで行う場合は、D’ Astous and Bitz(1995)
の 1 次元 1 項目を使用することを提案する。表 3 には、スポンサーフィットの測定尺度を示して いる ${ }^{2)}$ 。

\section{3. 分析方法}

スポンサーフィットの研究では、一般的に多変 量解析を用いられることが多く、分散分析、多 変量分散分析、重回帰分析、及び構造方程式モ デリングなどが分析方法として用いられている (Olson, 2010)。多変量分散分析とは、従属変数が 2つ以上、つまり多変数の平均值の差を吟味する ための分散分析のことである (Hair et al., 2010)。 これまでマーケティング分野における研究では、 分散分析や多変量分散分析が用いられることが多 く、一方でスポーツマーケティング分野では重回 帰分析や構造方程式モデリングを用いた研究が人 気を博している。これはアプローチの違いによる ものである。例えば、マーケティング分野にお けるスポンサーフィットの実験的研究では、コ ントロール群と非コントロール群に分類を行い、 コントロール群にプレスリリースを提示するこ とによって 2 群間のスポンサーフィットに差異 があるか検証がなされている (Roy and Cornwell, 2004)。つまり、原因(説明変数ないしは予測変数) と結果（被説明変数ないしは基準変数）とに峻別 した上で、両者の関係を統計的に明らかにしたり、 結果の予測を行ったりする方法である。

一方で、スポーツマーケティング分野における スポンサーフィット研究では、フィールドワーク 研究で得られたデータを基に、構造方程式モデ リングによる統合的なモデルの検証が多く行わ れている (e.g., Gwinner and Bennett, 2008; 山口ほ か, 2010）。構造方程式モデリングとは、構成概 念や観測変数の性質を調べるために集めた多くの 観測変数を同時に分析するための統計手法であり (Hair et al., 2010)、近年スポーツマーケティング 分野では主流の分析手法となっている。大西ほか （2011）は、スポーツマネジメント研究分野の学 術誌（ESQM、JSM、SMR）を用いて統計的分析 手法の検討を試みた。内容分析の結果、近年のス ポーツマネジメント研究は他分野と比較して、数 量的実証主義が拡大再生化されており、より高度 
表 3 スポンサーフィットの測定尺度

\begin{tabular}{|c|c|c|c|c|}
\hline 著者 & 構造 & $\begin{array}{l}\text { 多次元 } \\
\text { (副次元) }\end{array}$ & 尺度 & 測定尺度 \\
\hline $\begin{array}{l}\text { D'Astous and } \\
\text { Bitz (1995) }\end{array}$ & リンク & - & シングル & $\begin{array}{l}\text { 私は（企業名）と（イベント名）との結びつきは“とても強い／とても弱い” } \\
\text { と信じている }\end{array}$ \\
\hline $\begin{array}{l}\text { Gwinner and } \\
\text { Eaton (1999) }\end{array}$ & 類似性 & $\begin{array}{l}\text { (1) イメージ } \\
\text { (2) 機能 }\end{array}$ & $\begin{array}{l}\text { 1) リッカートタイプ } \\
\text { 2) セマンティック・ } \\
\text { ディファレンシャル }\end{array}$ & $\begin{array}{l}\text { イメージ } \\
\text { 1. (イベント名) と（ブランド名）は類似している } \\
\text { 2. (ブランド名) から連想されるアイデアは、(イベント名) から連想されるア } \\
\text { イデアと関連がある } \\
\text { 3. (イベント名) のイメージは、私が (ブランド名) に持っているイメージと } \\
\text { 大きく異なる } \\
\text { 機能 } \\
\text { 1. (イベント名) の参加者は、イベント中に（ブランド名）を使用しているだ } \\
\text { ろう } \\
\text { 2. 私が (イベント名) を観た時、私はしばしばイベント中に（ブランド名）を } \\
\text { 思い出す } \\
\text { 3. (ブランド名) は、(イベント名) における参加者が使用を検討する製品では } \\
\text { ない }\end{array}$ \\
\hline $\begin{array}{l}\text { Speed and } \\
\text { Thompson } \\
(2000)\end{array}$ & 一致 & イメージ & リッカートタイプ & $\begin{array}{l}\text { 1. (スポンサー名) と（イベント名）との間には、密接な結びつきがある } \\
\text { 2. (イベント名) のイメージと（スポンサー名）のイメージは類似している } \\
\text { 3. (スポンサー名) と（イベント名）はよく合っている } \\
\text { 4. (スポンサー名) と (イベント名) には多くの類似性がある } \\
\text { 5. (スポンサー名) が (イベント名) のスポンサーになることは意味がある }\end{array}$ \\
\hline $\begin{array}{l}\text { Roy and } \\
\text { Cornwell } \\
(2003)\end{array}$ & 一致 & イメージ & $\begin{array}{l}\text { セマンティック・ } \\
\text { ディファレンシャル }\end{array}$ & $\begin{array}{l}\text { 1. 肯定的である一否定的である } \\
\text { 2. 好意的である一好意的でない } \\
\text { 3. 良い一悪い } \\
\text { 4. 一致する一一致しない } \\
\text { 5. 互いに補足している一互いに補足していない } \\
\text { 6. 適切である一不適切である } \\
\text { 7. 筋が通っている一筋が通ってない } \\
\text { 8. とても合っている一全く合っていない } \\
\text { 9. ふさわしい一ろさわしくない }\end{array}$ \\
\hline
\end{tabular}

\begin{tabular}{|c|c|c|c|c|}
\hline $\begin{array}{l}\text { Rifon et al } \\
\text { (2004) }\end{array}$ & 類似性 & $\begin{array}{l}\text { (1) イメージ } \\
\text { (2) 機能 }\end{array}$ & $\begin{array}{l}\text { セマンティック・ } \\
\text { ディファレンシャル }\end{array}$ & $\begin{array}{l}\text { 1. 一致している一一致しない } \\
\text { 2. 良く合っている一全く合っていない } \\
\text { 3. 合致している一合致していない }\end{array}$ \\
\hline $\begin{array}{l}\text { Simmons } \\
\text { and Becker- } \\
\text { Olsen (2006) }\end{array}$ & 類似性 & イメージ & $\begin{array}{l}\text { セマンティック・ } \\
\text { ディファレンシャル }\end{array}$ & $\begin{array}{l}\text { 1. 類似している一類似していない } \\
\text { 2. 一致している-一致していない } \\
\text { 3. 典型的である一典型的でない } \\
\text { 4. 高いフィットである一低いフィットである } \\
\text { 5. 筋が通っている一筋が通ってない }\end{array}$ \\
\hline
\end{tabular}

1. (イベント名) は（ブランド名）について何か伝えている

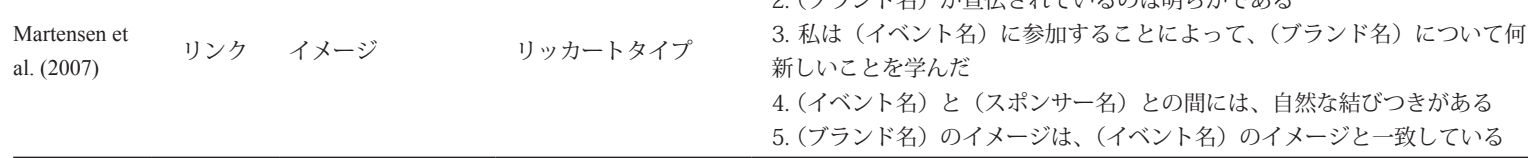

2. (ブランド名) が宣伝されているのは明らかである

5. (ブランド名) のイメージは、(イベント名) のイメージと一致している

\section{関連性}

1. 私は（企業名）が（イベント名）のスポンサーになっていることに警かない 2. (企業名) が (イベント名) のスポンサーになることを期待している

$\begin{array}{lll}\text { Fleck and } & \text { (1) 関連性 } & \\ \text { Quester } & \text { 一致 } & \text { (2) 予測性 }\end{array}$
3. (企業名) が、(イベント名) のスポンサーであることを予測できた 予測性

1. (企業名) が (イベント名) のスポンサーになることによって、何か私に伝 えている

2. (企業名) がスポンサーになることによって、企業の新たな側面を見つける ことができる

\begin{tabular}{|c|c|c|c|}
\hline $\begin{array}{l}\text { Pentecost } \\
\text { and Spence } \\
(2009)\end{array}$ & 類似性 & $\begin{array}{l}\text { （1）イメージ } \\
\text { (2) 性質 } \\
\text { (3) ベネフィット } \\
\text { /使用 }\end{array}$ & リッカートタイプ \\
\hline
\end{tabular}

イメージ
1. (ブランド名) と（イベント名）は類似したイメージを持っている
2. (ブランド名) から連想されるアイデアは、(イベント名) から連想されるア
イデアと似ている 


\begin{tabular}{|c|c|c|c|}
\hline & & (1) 可視性 & \\
\hline & & （2）明白さ & \\
\hline & & （3）スローガン & \\
\hline Zdravkovic & & $\begin{array}{l}\text { (4) ミッション } \\
\text { (5) カラー }\end{array}$ & 1) リッカートタイプ \\
\hline et al. (2010) & 䂓似性 & （6）ターゲット & $\begin{array}{l}\text { 2) セマンティック・ } \\
\text { ディファレンシャル }\end{array}$ \\
\hline & & （7）プロモーション & \\
\hline & & （8）地理的適合性 & \\
\hline & & $\begin{array}{l}\text { （9）ローカル特性 } \\
\text { （10）関与 }\end{array}$ & \\
\hline
\end{tabular}

(1) 可視性

(4) ミッション

7）プロモーション

（9）ローカル特性

(10) 関与
3. (ブランド名) のイメージは、(イベント名) の持つイメージと全く変わりは ない

性質

4. (ブランド名) に関連づけられる特徴は、（イベント名）に関連付けるられる 特徴を補完している

5. (ブランド名) と（イベント名）の特徴は似ている

6. (ブランド名) と（イベント名）は、類似した性質を共有している

ベネフィット/使用

7. 状況によっては、(ブランド名）の製品を（イベント名）中に使用すること ができる

8. (ブランド名) と（イベント名）は、互いを補完している

9. (ブランド名) から連想される要因は、（イベント名）から連想される要因と 同じベネフィットを提供している

\section{可視性}

1. 明白である一明白でない

2. 明瞭である一明瞭でない

3.はっきりしている一はっきりしていない

明白さ

4. 完全である一完全でない

5. 詳しい一あいまい

6. 良い一悪い

スローガン

7. (ブランド名) のスローガンは、(イベント名) とよく合っている

8. (ブランド名) のスローガンは、(イベント名) とうまく機能している

9. (ブランド名) のスローガンは、(イベント名)に取り入れられながら巧みな 語呂合わせになっている

10. (ブランド名) のスローガンは、(イベント名) と関連している

ミッション

11. (ブランド名) のミッションは、(イベント名) とよく合っている

12. (ブランド名) のミッションは、（イベント名）と同じような感情を発展さ せる

13. (ブランド名) のミッションは、（イベント名）の機能的な部分と関連があ る

カラー

14. (ブランド名) に使われているカラーは、（イベント名）とよく合っている 15. (ブランド名) に使われているカラーは、(イベント名) から連想されるカ ラーと似ている

16. (ブランド名) に使われているカラーは、(イベント名) を補完している ターゲット

17. (ブランド名) のターゲットユーザーは、（イベント名）とよく合っている 18. (ブランド名) のターゲットユーザーは、（イベント名）によって供給され た人々と似ている

19. (ブランド名) のターゲットユーザーは、（イベント名）に関連した人々を 思い出させる

プロモーション

20. (ブランド名) のプロモーションは、（イベント名）とよく合っている 21. (ブランド名) のプロモーションは、(イベント名) に関連した有名人を使っ ている

22. (ブランド名) のプロモーションは、(イベント名) を補完的に推奨してい る

\section{地理的適合性}

23. (ブランド名) に関連づけられた場所は、(イベント名）とよく合っている 24. (ブランド名) に関連づけられた場所は、（イベント名）に関連づけられた 場所と似ている

25. (ブランド名) に関連づけられた場所は、（イベント名）が運営されている 場所と合っている

ローカル特性

26. (イベント名) は、（地域名）とよく合っている

27. (イベント名) は、密接に（地域名）と関連している

28. (イベント名) は、非常に（地域名）と関係がある 


\section{関与}

29. (ブランド名) は、（イベント名）に関わる消費者を励ましている

30. (ブランド名) のミッションは、（イベント名）との関わり合いを促してい

る

31. (ブランド名) は、(イベント名) における消費者の関与に大きく貢献して いる

\begin{tabular}{ll} 
& いる \\
\hline イメージ & 1. イベントゲランドは、同じイメージを持っているためよく合っている \\
& 2. イベントとブランドは、異なったイメージを持っているためあまり合ってい \\
& ない \\
& 機能
\end{tabular}

\begin{tabular}{|c|c|c|c|}
\hline Drenger et & 一致 & $\begin{array}{l}\text { (1) イメージ } \\
\text { (2) 機能 }\end{array}$ & リッカートタイプ \\
\hline & & （3） ユーザー & \\
\hline
\end{tabular}

3. ブランドの製品がイベントに扔いて役に立っているため、イベントとブラン ドはよく合っている

4. ブランドの製品がイベントにおいて役立っていないため、イベントとブラン ドはあまり合っていない

ユーザー

5. イベントに参加中、ブランドが人々とマッチしているため、イベントとブラ ンドはよく合っている

6. イベントに参加中、ブランドが人々とマッチしていないため、イベントとブ ランドはあまり合っていない

イメージ

1. 興奮している一興奮していない

2. 正直である一正直でない

3. 親切である一不親切である

4. ユニークである一平凡である

5. 現代的である一古風である

6. 成功している一成功していない

7. 魅力がある一魅力がない

8. 強い一弱い

使用

\begin{tabular}{|c|c|c|c|}
\hline \multirow{4}{*}{$\begin{array}{l}\text { Olson and } \\
\text { Thjømøe } \\
(2011)\end{array}$} & \multirow{5}{*}{ 類似性 } & （1）使用 & \multirow{4}{*}{$\begin{array}{l}\text { 1) リッカートタイプ } \\
\text { 2) セマンティック } \\
\text { ディファレンシャル }\end{array}$} \\
\hline & & (2) 卓越 & \\
\hline & & (3) 観䈨 & \\
\hline & & & \\
\hline & & (6) イメージ & \\
\hline
\end{tabular}

9. どれくらい（スポンサー名）の製品は、（イベント名）の参加者によって使 われているか?

10. テレビに㧧て (イベント名) を観ている際、どれくらい観客は (スポンサー 名）の製品を使用しているか?

\section{卓越}

スポンサーは、

11. 大きい (イベント名) である一小さい（イベント名）である

12. 重要である一重要でない

锶衆

13. どれぐらい（スポンサー名）の顧客が（イベント名）の観客なのか？ 地理

14. グローバルである一ローカルである

15. 国際的である一ローカルである

態度

16. 良い評判がある一悪い評判がある

17. 好意的なイメージがある一否定的なイメージがある

な統計的分析手法が用いられていることを明らか にしている。

総じて言えることは、これまでのスポンサー フィット研究は実験的研究を行う場合、分散分析 や多変量分散分析が用いられることが多い。一方 で、フィールドワーク研究の場合、重回帰分析 や構造方程式モデリングを用いたモデルの検証 が多く行われる傾向にある。しかしながら、実 験的研究における分散分析などの手法は、スポ
ンサーフィットの連続体（スポンサーフィット 、スポンサーへの態度 $\rightarrow$ 購入意図）としての概 念的階層性の検証が難しく、一方でフィールド ワーク研究における構造方程式モデリングなどの 手法は、現場でのワンショットサーベイが中心に なるため、時系列的な検証、すなわち縦断的な 研究を行うことが困難である。したがって、前述 でも述べたように、今後は実験的研究を基にした フィールドワーク研究を行う必要があり、それら 
のリサーチデザインに基づいた分析手法を選択す ることが望まれる。

\section{4. スポンサーフィットの先行要因と結果要因に 関する研究}

\section{1. 先行要因}

これまでスポンサーフィットの先行要因に関 する研究は、Roy and Cornwell（2004）や山口ほ か（2010）が指摘するように、その数は決して 多くない。しかしながら、いくつかの研究では先 行要因の検証が行われている。例えば、Roy and Cornwell（2004）によると、消費者の知識がスポ ンサーフィットには重要な要因だと説明してい る。また Gwinner and Bennett（2008）と山口ほか （2010）は、ブランド凝集性とスポーツ・アイデ ンティフィケーションがスポンサーフィットに 影響を及ぼすことを明らかにしている。さらに、 Lacey and Close (2013) は、イベントに対する積 極性、イベントへの態度、及びブランド知識の三 つの要因がスポンサーフィットに影響を及ぼすこ とを立証している。

これまでの先行研究のレビューから、ブランド 凝集性やブランド知識といったブランドに対する 事前の知識がスポンサーフィットに影響を及ぼす ことが考えられる。これはRoy and Cornwell(2004) も同様の見解を示している。次に、イベントに対 する積極性やイベントへの態度といったイベン トに対する事前の知識がスポンサーフィットの先 行要因になりうる可能性が考えられる。なぜな ら、消費者はイベント経験が多い人ほど、イベン トとスポンサーとのフィットが高まる傾向にあり (Roy and Cornwell, 2004)、またイベントやスポン サーに対し、好意的な態度を示すことが過去の先 行研究で報告されているためである（Martensen, et al., 2007)。最後に、Gwinner and Bennett（2008） や山口ほか（2010）が明らかにしたように、ス ポーツ・アイデンティフィケーションといったス ポーツに対する忠誠心・愛着がスポンサーフィッ トに影響を及ぶことが推察される。つまり、ス ポーツイベントにスポンサードする企業並びに主 催者は、単にスポーツイベント開催期間中にマー
ケティング活動を行うのではなく、イベント開催 前から消費者の目に触れ、知識となるようなマー ケティング活動並びにイベントの告知を積極的に 行う必要があるだろう。そういった意味では、才 リンピック・パラリンピック競技大会における TOP パートナー制度や FIFA ワールドカップにお ける FIFA パートナー制度などは、イベントの商 標権を守りつつ、スポンサードする企業の権利を 最大化する意味で、大変参考になるマーケティン グ手法である。今後こうしたメガ・スポーツイベ ントのマーケティング手法を、他のスポーツイベ ントも参考にする必要があり、その際スポーツと の親和性などを消費者に伝えることも重要であろ う。そうした取り組みを行うことで、スポンサー フィットを高める要因になることが考えられる。

\section{2. 結果要因}

スポンサーフィットの結果要因に関する研究 は、イベントとスポンサーが消費者の記憶の中で 知覚的に一致することで、様々な効果があったこ とが報告されている。例えば、ブランド認知 (Johar and Pham, 1999)、スポンサーへの態度（McDaniel, 1999; Simmon and Becker-Olsen, 2006; Pappu and Cornwell, 2014)、ブランドイメージ (Gwinner and Eaton, 1999; Becker-Olsen and Simmons, 2002)、ブ ランドへの態度 (Speed and Tompson, 2000; Koo et al., 2006; Lee and Cho, 2009; 山口ほか, 2010)、 スポンサーに対するコミットメント (Lacey and Close, 2013)、ブランドへの好意 (Speed and Thompson, 2000)、ブランドへのロイヤリティ (Sirgy et al., 2008)、イメージの転移 (Gwinner, 1997; Gwinner and Eaton, 1999)、ポジショニング の明瞭さ (Simmon and Becker-Olsen, 2006; Pappu and Cornwell, 2014)、スポンサーシップ反応 (Speed and Thompson, 2000; Deitz et al., 2012)、購入意図 (Gwinner and Bennett, 2009; Lee and Cho, 2009; 山 口ほか，2010）などである。

これまでの先行研究のレビューから、スポン サーへの態度やブランドへの態度といったスポン サー企業に対する態度がスポンサーフィットの 結果要因の 1 つになることが考えられる。これ は Simmons and Becker-Olsen（2006）や Pappu and 
Cornwell（2014）に代表されるスポンサーフィッ トの研究においても同様の見解がなされている。 つまり、スポーツイベントを例に挙げると、消費 者はスポーツイベントの会場内において、スポ ンサードする企業から何らかの刺激を受けるこ とにより、それがスポンサーへの好意的な態度 に繋がることが示唆される（山口ほか，2010）。 次にブランドイメージや企業イメージといった スポンサー企業に対するイメージがスポンサー フィットの結果要因になりうる可能性が考えら れる。これまで多くの先行研究において同様の 指摘がなされていることから (e.g., Gwinner and Eaton, 1999; Speed and Thompson, 2000)、イベント とスポンサーが消費者間で知覚的に一致すること で、スポンサー企業に対するイメージは向上する ことが考えられる。さらに、過去の先行研究で指 摘されているように (Sirgy et al., 2008; Lacey and Close, 2013)、スポンサーフィットが高まること で、スポンサーに対するコミットメントやブラン ドへのロイヤリティといったスポンサー企業に対 する忠誠心・愛着が高まることが示唆される。そ して、Gwinnerに代表される先行研究で実証され ているように (Gwinner, 1997; Gwinner and Eaton, 1999)、スポンサーフィットが高まることで、イ ベントのイメージがブランドのイメージへ転移す
る可能性が考えられる。加えて、先行研究で明 らかになったように (Simmon and Becker-Olsen, 2006; Pappu and Cornwell, 2014)、ポジショニング の明瞭さがスポンサーフィットの重要な結果要因 になることが考えられる。ポジショニングの明瞭 さとは、消費者が企業に何を期待するかの程度で ある（Simmon and Becker-Olsen, 2006）。つまりス ポンサーフィットが高い場合、消費者が企業に期 待するものと企業が行うスポンサー活動が一致し ていると考えることができる。最後に、多くの先 行研究で指摘されているように (e.g., Speed and Thompson, 2000; Gwinner and Bennett, 2009)、スポ ンサーフィットが高まることで、消費者のスポン サーシップ反応は高まり、スポンサー企業の製品 に対する購入意図が高まる可能性が考えられる。 一方で、ブランド認知については、スポンサー企 業を認知していることが前提となっており、もし スポンサー企業を認知していない場合、ブランド 認知がスポンサーフィットの結果要因となりうる ことは考えづらい。むしろ、ブランド認知はスポ ンサーフィットの先行要因と考える方が自然であ る。図 1 には、先行研究より導き出された先行 要因と結果要因を示している。

\begin{tabular}{|c|c|}
\hline \multirow{2}{*}{$\begin{array}{l}\text { ブランドに対する事前の知識 } \\
\text { •ブランド凝集性 (Gwinner and Bennett, } \\
\text { 2008,山住か, 2010) } \\
\text { ブランド知識 (Roy and Cornwell, 2004; } \\
\text { Lacey and Close, 2013) } \\
\text { ブランド認知 }\end{array}$} & $\begin{array}{l}\text { スポンサー企業に対する態度 } \\
\text { ・ スポンサーへの態度 (McDaniel, 1999; Simmon and } \\
\text { Becker-Olsen, 2006; Pappu and Cornwell, 2014) } \\
\text { ・ ブランドへの態度 (Speed and Tompson, 2000; } \\
\text { Koo et al., 2006; Lee and Cho, 2009) }\end{array}$ \\
\hline & \multirow{2}{*}{$\begin{array}{l}\text { スポンサー企業に対するイメージ } \\
・ \quad \text { ブランドイメージ (Gwinner and Eaton, 1999; } \\
\text { Becker-Olsen and Simmons, 2002) }\end{array}$} \\
\hline \multirow{2}{*}{$\begin{array}{l}\text { イベントに対する事前の知識 } \\
\cdot \text { イベントに対する積極性（Lacey and } \\
\text { Close, 2013） } \\
\text { イベントへの態度（Lacey and } \\
\text { Close, 2013） }\end{array}$} & \\
\hline & \multirow{2}{*}{ 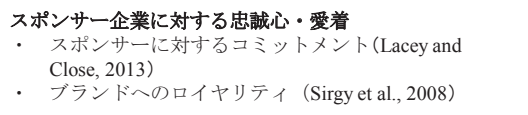 } \\
\hline \multirow{5}{*}{$\begin{array}{l}\text { スポーツに対する忠誠心・愛着 } \\
・ \quad \text { スポーツ・アイデンティ } \\
\text { フィケーション (Gwinner and Bennett, } \\
\text { 2008,山口ほか, 2010) }\end{array}$} & \\
\hline & $\begin{array}{l}\text { イメージの転移 } \\
\text { (Gwinner, 1997; Gwinner and Eaton, 1999) }\end{array}$ \\
\hline & \multirow{2}{*}{$\begin{array}{l}\text { ポジショニングの明瞭さ } \\
\text { (Simmon and Becker-Olsen, 2006; Pappu and Cornwell, 2014) }\end{array}$} \\
\hline & \\
\hline & 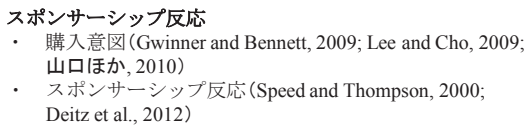 \\
\hline
\end{tabular}




\section{まとめ}

本研究では、これまで欧米で行われたスポーツ イベントに扱るスポンサーフィットに関する研 究動向を整理し、大局的かつ客観的に総括するこ とを目的とした。先行研究を基にレビューを行っ た結果、（1）スポンサーフィットの構成概念に 関する研究、(2) スポンサーフィットの理論的 アプローチに関する研究、(3) スポンサーフィッ トの測定尺度と方法論に関する研究、(4) スポ ンサーフィットの先行要因と結果要因に関する研 究の 4 つに分類することができた。また、本レ ビューによって得られた主な結果は以下のように まとめることができる。

1.スポンサーフィットの定義に関しては、成熟期 に達しており、先行研究の概念整理を基に、類 似性の視点から、スポンサーフィットを定義で きることが明らかとなった。一方でスポンサー フィットの構造（多次元性、下位次元）におい ては、まだまだ発展期にあり、現段階で 1 次 元から 10 次元まで多種多様な構造があること が確認された。

2. スポンサーフィットの理論的アプローチに関し ては、一致理論、自己一致理論、スキーマ理論、 連想ネットワーク理論、帰属理論、及びマッチ アップ仮説がスポンサーフィット研究に用いら れていることが確認された。

3. スポンサーフィットのデータ収集に関しては、 母集団の特定が困難なことから、1つ1つの現 象をケーススタディとしてまとめることが重要 であり、その際実験的研究を基にしたフィール ドワーク研究を行う必要性が確認された。また 測定尺度においては、シングルアイテム尺度、 リッカートタイプ尺度、及び SD 法を用いた尺 度が適用されている。そして分析方法に関して は、実験的研究を行う場合、分散分析や多变量 分散分析が用いられることが多く、フィールド ワーク研究を行う場合、重回帰分析や構造方程 式モデリングを用いたモデルの検証が多く行わ れていることが明らかとなった。
4.スポンサーフィットの先行要因に関しては、成 長期にあり、ブランドに対する事前の知識、イ ベントに対する事前の知識、及びスポーツに対 する忠誠心・愛着がスポンサーフィットに影 響を及ぶことが確認された。一方スポンサー フィットの結果要因においては、成熟期に達し ており、スポンサーフィットが高まることで、 スポンサー企業に対する態度、イメージ、忠誠 心・愛着、イメージの転移、ポジショニングの 明瞭さ、スポンサーシップ反応、及び購入意図 に影響を及ぼすことが明らかとなった。

\section{今後の研究課題}

上記の分類から得られた結果を基に、次にスポ ンサーフィットの研究課題について述べることと する。第 1 点目に、尺度の検討である。これま でスポンサーフィットの尺度開発はいくつか行わ れてきたものの (e.g., Zdravkovic et al., 2010; Olson and Thjømøe, 2011)、その数は決して多いとは いえない。近年は、スポンサーフィットの新たな 視点として、ポートフォリオの概念を用いたポー トフォリオ・フィット (Chien et al., 2011; Groza et al., 2012) やブランド・パーソナリティの概念を 用いたパーソナリティ・フィット (Lee and Cho, 2009, 2012; Cho and Kang, 2012; 山口ほか, 2014) などの研究が行われている。彼らの見解では、研 究者のアプローチの仕方や国、イベント、及びブ ランドのコンテクストの違いによって、スポン サーフィットの構成要素は異なることが明らかに されている。したがって今後は、単にスポンサー フィットを尺度化するのではなく、新たな視点を 盛り込んだ尺度開発が望まれ、その際理論的なア プローチやイベント開催国の社会文化的背景も含 めて検討することが必要であろう。

第 2 点目に、包括的なモデルの検討である。 これまでのスポンサーフィット研究は、モデルの 構築プロセスと理論的な厳格さに欠けていること がしばしば批判されている（Cornwell et al., 2005; Prendergast et al., 2010)。Rifon et al. (2004) はモ デルを作成する際、スポンサーフィットの多次元 
的な側面を無視しながら、単一の構成概念として スポンサーフィットは概念化されてきたことを報 告している。また Olson and Thjømøe(2011)によっ て、スポンサーフィットの下位次元を含んだモデ ルの検証は行われているが、スポンサーフィット の連続体（スポンサーフィットースポンサーへの 態度 $\rightarrow$ 購入意図）としての概念的階層性の検証は 行われていない。またスポーツマーケティング研 究の他の分野と比較して、調整変数の検討があま り行われていないのが現状である。これまでい くつかのスポンサーフィット研究において調整 変数の検討は試みられているが (Dees et al., 2010; Deitz et al., 2012; Grohs and Reisinger, 2014)、どの 変数がスポンサーフィットを調整しながら、従属 変数に影響を及ぼしているかは定かではない。吉 田（2011）によると、要因間の関係性の強弱を 決定づける環境や対象を絞り込むことは重要だ と指摘している。したがって今後は、Cornwell et al.（2005）が指摘するように、スポンサーフィッ トの連続体を含んだ包括的なモデルの発展が望ま れ、その際調整変数の検討も合わせて行う必要が あるだろう。

第 3 点目に、方法論の検討である。スポンサー フィット研究は、現場のエキスパート、すなわち スポーッマーケターの経験や知識が極めて重要な 領域である。彼らはスポンサー企業となりうるク ライアントの要望に基づき、スポンサー活動を展 開し、投資に見合った見返りを提供するため、ス ポンサーとイベントとの間のフィットを見出し、 スポンサーシップ・リンク・マーケティングを展 開することが彼らのマネジメントゴールとなって いる (Cornwell et al., 2006)。よって、彼らの経験 的アプローチは無視することができない。しかし ながら、経験的アプローチだけでは、意見のバイ アスが生じ、客観性に欠ける可能性は否めない。 したがって、研究者が介入した理論的アプローチ に基づく研究結果をクライアントに提示すること が求められる。今後スポンサーフィット研究は、 現場のスポーツマーケターと協力しながら、現場 $\rightarrow$ 理論 $\rightarrow$ 実験的研究 $\rightarrow$ フィードワーク研究 $\rightarrow$ 現 場といった手順を踏みながら、研究結果を明らか
にすることが望まれ、それらの結果を基にクライ アントにフィードバックする必要があるだろう。

最後に、今後の研究展望と研究の限界について 述べることとする。第 1 点目に、行動的尺度や 生理的尺度を用いたスポンサーフィットの測定で ある。一般的にスポンサーフィットは記憶の中で、 どのようにスポンサーがイベントとフィットする かというメカニズムを測定するものであり、心理 的尺度を用いた質問紙調査では限界がある。押見 （2013）によると、今後消費者行動を検証する手 法として注目されるのは、行動的尺度と生理的 尺度を用いた研究だと述べており、竹村（2012） はf-MRI（磁気共鳴機能断層撮影）等を用いて脳 の活動を測定・検証する、「ニューロマーケティ ング」が今後発展する研究分野だと指摘してい る。これまでスポンサーフィット研究ではこうし た装置を用いた生理学的実験研究は行われていな いが、科学の進歩、学術の貢献といった側面を考 えれば、こうした研究も今後必要になるだろう。

第 2 点目に、本論文は欧米で行われたスポン サーフィットの研究動向を整理することを試みた が、全ての研究を網羅したわけではない。本研究 では、内容分析によってレビューを実施したが、 システマティックレビューやメタアナリシスの手 法を用いることで、詳細な因果関係や新たな研究 視座が得られる可能性がある。したがって、レ ビュー研究を実施する際は、こうしたレビュー手 法も参考にする必要があるだろう。本研究が、ス ポーツマーケティング及びスポンサーシップの発 展に寄与する一資料になれば幸いである。

\section{【注】}

1）プレスリリースとは、企業などの組織体が、新聞 社や雑誌社などの報道関係者に対して対外的に発 表する広報を指す。

2) 表 3 に掲載しているスポンサーフィットの尺度は、 一部バックトランスレーションを行わず、著者の 判断で翻訳を行っている。したがって、それらの 尺度を使用する際は、原文を読みながら質問項目 を確認すると共に、バックトランスレーションや パネルディスカッションの手法を用い、再度翻訳 することをお勧めしたい。 


\section{【謝辞】}

本研究を進めるにあたり、長きにわたりご指導、 ご助言をいただきました順天堂大学スポーツ健康科 学部野川春夫特任教授と神戸大学発達科学部山口泰 雄教授に厚く御礼を申し上げます。また本論文の作 成にあたり、オレゴン大学 T. Bettina Cornwell 教授に も、数多くの貴重なご助言を賜りました。ここに感 謝の意を表します。ありがとうございました。

\section{【文献】}

Aaker, D. A. (1991) Managing brand equity, San Francisco: Free Press.

Bartlett, E.C. (1932) Remembering: A study in experimental and social psychology (2nd Ed.). Cambridge: Cambridge University Press, England.

Becker-Olsen, K. L., and Simmons, C. J. (2002) When do social sponsorships enhance or dilute equity? Fit, message source, and the persistence of effects. Advances in Consumer Research, 29(1): 287-289.

Becker-Olsen, K. L., and Hill, R. P. (2006) The impact of sponsor fit on brand equity: The case of nonprofit service providers. Journal of Service Research, 9(1): 73-83.

Chien P. M., Cornwell, T. B., and Pappu, R. (2011) Sponsorship portfolio as a brand-image creation strategy. Journal of Business Research, 64: 142-149.

Cho, S., and Kang, J. H. (2012) Psychometric comparability of brand personality scale: Assessing brand personality matching between sports and corporate sponsors by using the congeniality test. International Journal of Sports marketing \& Sponsorship, 13(4): 295-312.

Close, A. G., and Lacey, R. (2013) Fit matters? Asymmetrical impact of effectiveness on sponsors and event marketers. Sport Marketing Quarterly, 22: 71-82.

Collins, A. M., and Loftus, E. F. (1975) A spreading activation theory of semantic processing. Psychological Review, 82: 407-428.

Cornwell, T. B., and Maignan, I. (1998) An international review of sponsorship research. Journal of Advertising, 27(1): 1-21.

Cornwell, T. B., Weeks, C. S., and Roy, D. P. (2005) Sponsorship-linked marketing: Opening the black box. Journal of Advertising, 34(2): 21-42.

Cornwell, T. B., Michael S. H., Angela M. M., Clinton S. W., and Cassandra L. T. (2006) Sponsorship-linked marketing: The role of articulation in memory. Journal of Consumer Research, 33(3): 312-321.

Cornwell, T. B., and Kwon, Y. (2010) Another decade of sponsorship research reviewed. Paper presented at the 25th conference of North American Association for Sport Management. Tampa, FL, USA.

Cornwell, T. B. (2012) Sponsorship-linked marketing 2.0. 60-minute plenary breakfast discussion at the research conference in sports marketing: Focus on sponsorship,
Portland, OR, USA.

Cornwell, T. B. (2014) Sponsorship in marketing: Effective communications through sports, arts and events. Routledge Publishers: UK, pp.87-90.

D'Astous, A., and Bitz, P. (1995) Consumer evaluations of sponsorship program. European Journal of Marketing, 29(12): 139-173.

Dees, W., Bennett G., and Ferreira. M. (2010) Personality fit in NASCAR: An evaluation of driver-sponsor congruence and its impact on sponsorship effectiveness outcomes. Sport Marketing Quarterly, 19: 25-35.

Deitz, D. D., Myers, S. W., and Stafford, M. R. (2012) Understanding consumer response to sponsorship information: A resource-matching approach. Psychology \& Marketing, 29(4): 226-239.

Drengner, J., Jahn, S., and Zanger, C. (2011) Measuring event-brand congruence. Event Management, 15(1): 2536.

Fiske, S.T., and Taylor, S.E. (1991) Social cognition (2nd ed.). McGraw-Hill, NY, USA.

Fleck, N., and Quester, P. (2007) Birds of a feather flock together. . . definition, role and measure of congruence: An application to sponsorship. Psychology \& Marketing, 24: 975-1000.

Groza, M. D., Cobbs, J., and Schaefers, T. (2012) Managing a sponsored brand: The importance of sponsorship portfolio congruence. International Journal of Advertising, 31(1): 63-84.

Grohs, R. and Reisinger, H. (2014) Sponsorship effects on brand image: The role of exposure and activity involvement. Journal of Business Research, 67: 10181025 .

Gwinner, K. P. (1997) A model of image creation and image transfer in event sponsorship. International Marketing Review, 14: 145-158.

Gwinner, K. P., and Eaton, J. (1999) Building brand image through event sponsorship: The role of image transfer. Journal of Advertising, 4: 47-57.

Gwinner, K. P., and Bennett, G. (2008) The impact of brand cohesiveness and sport identification on brand fit in a sponsorship context. Journal of Sport Management, 22: 410-426.

Hair, J. F., Black, W. C., Babin, B. J., and Anderson, R. E. (2010) Multivariate data analysis: A global perspective (7th Ed.). Prentice Hall, Upper Saddle River, New Jersey. Han, S., Choi, J., Kim, H., Davis, J. A., and Lee, K. (2013) The effectiveness of image congruence and the moderating effects of sponsor motive and cheering event fit in sponsorship. International Journal of Advertising, 32(2): 301-317.

原田宗彦（2007）権利ビジネスとスポーツ. 原田宗 彦 (編著) スポーツ産業論第 4 版. 杏林書院: 東京, pp.240-244.

原田宗彦・小笠原悦子 (2008) スポーツマネジメント. 
大修館書店：東京.

Hermann, J., Walliser, B., and Kacha, M. (2011) Consumer consideration of sponsor brands they do not remember: Taking a wider look at the memorization effects of sponsorship. International Journal of Advertising, 30(2): 259-281.

Hsieh, H., and Shannon, S. E. (2005) Three approaches to qualitative content analysis. Qualitative Health Research, 15(9): 1277-1288.

藤本淳也（2008）スポーツ・スポンサーシップ. 原 田宗彦 (編著) スポーツ・マーケティング. 大修 館書店：東京.

池上和男（2006）マーケティング・コミュニケーシ ヨン大辞典. 宣伝会議：東京, pp.361.

Jagre, E., Watson, J. J., and Watson, J. G. (2001) Sponsorship and congruity theory: A theoretical framework for explaining consumer attitude and recall of event sponsorship. Advances in Consumer Research, 28: 439-445.

Javalgi, R. G., Traylor, M. B., Gross, A. C., and Lampman, E. (1994) Awareness of sponsorship and corporate image: An empirical investigation. Journal of Advertising, 23: 47-58.

Johan, G. V. and Pham, M. T. (1999) Relatedness, prominence, and constructive sponsor identification. Journal of Marketing Research, 36: 299-313.

Kamins, M. (1990) An investigation into the 'match-up' hypothesis in celebrity adverting: When beauty is only skin deep. Journal of Advertising, 19(1): 4-13.

Kelley. H. H. (1973) The process of causal attribution. American Psychologist, 28: 107-128.

Keller, K. (1993) Conceptualizing, measuring, and managing customer-based brand equity. Journal of Marketing, 57(1): 1-22.

Keller, K. L. (2003) Strategic brand management: Building, measuring and managing brand equity (2nd Ed.) Prentice Hall, New Jersey.

Koo, G., Quarterman, J., and Flynn, L. (2006) Effect of perceived sport event and sponsor image fit on consumers' cognition, affect, and behavioral intentions. Sport Marketing Quarterly, 15: 80-90.

Lacey, R., and Close, A. G. (2013) How fit connects service brand sponsors with consumers' passions for sponsored events. International Journal of Sports Marketing \& Sponsorship, 14(3): 212-228.

Lee, H. S., and Cho, C. H. (2009) The matching effect of brand and sporting event personality: Sponsorship implications. Journal of Sport Management, 23(1): 4164.

Lee, H. S., and Cho, C. H. (2012) Sporting event personality: Scale development and sponsorship implications. International Journal of Sports marketing \& Sponsorship, 14(1): 51-67.

Martensen, A., Grønholdt, L., Bendtsen, L., and Jensen, M.
J. (2007) Application of a model for the effectiveness of event marketing. Journal of Advertising Research, 47(3): 283-301.

McCarville, R. E., and Copeland, R. P. (1994) Understanding sport sponsorship through exchange theory. Journal of Sport Management, 8(2): 102-114.

McDaniel, S. R. (1999) An investigation of match-up effects in sport sponsorship advertising: The implications of consumer advertising schemas. Psychology and Marketing, 16(2): 163-184.

McDonald, C. (1991) Sponsorship and the image of the sponsor. European Journal of Marketing, 25: 31-38.

Musante, M., Milne, G. R.., and McDonald, M. A. (1999) Sport sponsorship: Evaluating the sport and brand image match. International Journal of Sports Marketing \& Sponsorship, 1(1): 32-47.

Nan, X., and Heo, K. (2007) Consumer responses to corporate social responsibility (CSR) initiatives: Exaning the role of brand-cause fit in cause-related marketing. Journal of Advertising, 36(2): 63-74.

Olson, E. L. (2010) Does sponsorship work in the same way in different sponsorship contexts? European Journal of Marketing, 44(1/2): 180-199.

Olson, E. L., and Thjomoe, H. M. (2011) Explaining and articulating the fit construct. Journal of Advertising, 40(1): 57-70.

大西孝之・原田宗彦・押見大地 (2011) スポーツマ ネジメント研究における統計的分析手法：2004 年 から 2010 年にESMQ、JSM、SMRに掲載された 学術論文の内容分析. スポーツマネジメント研究, 3 (1) : 45-60.

押見大地（2013）生体反応から見たファン行動を探 る. 原田宗彦・押見大地・福原崇之（編著）J リ ーグマーケティングの基礎知識. 創文企画 : 東京, pp.56-63.

Pentecost, R. D., and Spence, M. T. (2009) Spill-over effects in multi-sponsored events: Theoretical insights and empirical evidence. World Journal of Management, 1(1): 95-117.

Pappu, R., and Cornwell, T. B. (2014) Corporate sponsorship as an image platform: Understanding the roles of relationship fit and sponsor-sponsee similarity. Journal of the Academy of Marketing Science, 42(5): 490-510.

Prendergast, G. P., Poon, D., and West, D. C. (2010) Match game: Linking sponsorship congruence with communication outcomes. Journal of Advertising Research, 50(3): 214-226.

Pham, M. T., and Johar, G. V. (2001) Market prominence biases in sponsor identification: Processes and consequentiality. Psychology and Marketing, 18: 123143.

Quester, P., Plewa, C., Palmer, K., and Mazodier, M. (2013) Determinants of community-based sponsorship impact 
on self-congruity. Psychology and Marketing, 30(11): 996-1007.

Rifon, N., Choi, S., Trimble, C., and Li, H. (2004) Congruence effects in sponsorship: The meadiating role of sponsor credibility and consumer attributions of sponsor motive. Journal of Adverting, 33(1): 29-42.

Roy, D. P., and Cornwell, T. B. (2003) Brand equity's influence on responses to event sponsorship. Journal of Product and Brand Management, 12(6/7): 377-393.

Roy, D. P., and Cornwell, T. B. (2004) The effects of consumer knowledge on responses to event sponsorships. Psychology \& Marketing. 21(3): 185-207.

Ruth, J., and Simonin, B. (2003) Brought to you by brand A and brand B: Investigating multiple sponsors' influence on consumers' attitudes toward sponsored events. Journal of Advertising, 32(3): 19-30.

Simmons, C. J., and Becker-Olsen, K. L. (2006) Achieving marketing objectives through social sponsorships. Journal of Marketing, 70(4): 154-69.

Simons, H. W., Berkowitz, N. N., and Moyer, R. J. (1970) Similarity, credibility, and attitude change: A review and a theory. Psychological Bulletin, 73: 1-16.

Sirgy, M. J., Lee, D. J., Johar, J. S., and Tidwell, J. (2008) The effect of self-congruity with sponsorship on brand loyalty. Journal of Business Research, 61(10): 1091 1097.

Smith, G. (2004) Brand image transfer through sponsorship: A consumer learning perspective. Journal of Marketing Management, 20: 457-474.

Speed, R., and Thompson, P. (2000) Determinants of sports sponsorship response. Journal of the Academy of Marketing Science, 28: 226-238.

Stipp, H. (1998) The impact of Olympic sponsorship on corporate image. International Journal of Advertising, 17: $75-87$

竹村和久 (2012) 消費者行動研究のこれから. 守口剛・ 竹村和久 (編著) 消費者行動研究：購買心理から ニューロマーケティングまで.八千代出版 : 東京, pp.181-200

Tauber, E. M. (1988) Brand leverage: Strategy for growth in a cost-control world. Journal of Advertising Research, 28: 26-30.

辻洋右（2011）スポーツスポンサーシップ研究概説. スポーツマネジメント研究，3（1）：23-34.

Walliser, B. (2003) An international review of sponsorship research: Extension and update. International Journal of Advertising, 22: 5-40.

Weeks, C. S., Cornwell T. B., and Drennan J. C. (2008) Leveraging sponsorships on the internet: Activation, congruence, and articulation. Psychology and Marketing, 25(7): 637-654

Woisetschläger, D. M., and Michaelis, M. (2012) Sponsorship congruence and brand image: A pre-post event analysis. European Journal of Marketing, 46(3/4):
509-523.

山口志郎・野川春夫・北村薰・山口泰雄（2010）ス ポーツイベントのスポンサーシップにおけるスポ ンサーフィットに関する研究 : Gwinner and Bennett モデルの検証. スポーツマネジメント研究, 2 (2): 147-161.

山口志郎・野川春夫・山口泰雄（2014）冠スポーツ イベントにおけるパーソナリティ・フィットが消 費者の購買行動に及ぼす影響：ブランド・パーソ ナリティを用いた定量分析. 生涯スポーツ学研究, 11 (1) : 13-25.

吉田政幸（2011）スポーツ消費者行動：先行研究の 検討. スポーツマネジメント研究, 3（1）：5-21.

Zdravkovic, S., Magnusson, P., and Stanley, S. M. (2010) Dimensions of fit between a brand and a social cause and their influence on attitudes. International Journal of Research in Marketing, 27: 151-160.

Zdravkovic, S., and Till, B. (2012) Enhancing brand image via sponsorship strength of association effects. International Journal of Advertising, 31(1): 113-132.

$$
\left(\begin{array}{l}
2014 \text { 年 } 6 \text { 月 } 16 \text { 日 受付 } \\
2014 \text { 年 } 11 \text { 月 } 19 \text { 日受理 }
\end{array}\right)
$$

